\title{
Sexual dimorphism in Aegla marginata (Decapoda: Anomura)
}

\author{
André Trevisan, Murilo Zanetti Marochi, Marcelo Costa, Sandro Santos and Setuko Masunari
}

(AT, MZM, MC, SM) Department of Zoology, Institute of Biological Sciences, Federal University of Paraná. Centro Politécnico, Jardim das Américas, Caixa Postal 19020, 81531-980, Curitiba, Paraná, Brazil. E-mails: (AT) andretrevisan@ufpr.br; (SM) setmas@ufpr.br

(SS) Laboratory of Carcinology, Federal University of Santa Maria. Av. Roraima 1000, Cidade Universitária, Bairro Camobi, 97105-900, Santa Maria, Rio Grande do Sul, Brazil. E-mail: ssantos@ccne.ufsm.br

Abstract

A study on sexual dimorphism in Aegla marginata was conducted using geometric morphometric methods. The carapace of 47 females and 75 males and the left and right cheliped propodus of 29 females and 40 males were analyzed. Eighteen landmarks were established in the carapace and 10 in the cheliped propodus. A Generalized Procrustes Analysis based on landmark configurations was used to separate the components of size and shape. A Student t-test was used to determine whether statistically significant sexual dimorphism was shown by the carapace and the cheliped propodus. The variation in the shape of the structures was evaluated with a discriminant analysis. Our results show that there is no sexual dimorphism in the carapace of $A$. marginata. However, the size of the propodus differed statistically between the sexes. The carapace shape differed between the sexes: the females showed a wider posterior area and a narrower anterior area than the males. The shape of the cheliped propodus also differed between the sexes: overall, the females had a longer and narrower cheliped propodus than the males. The variations in the carapace shape found in this study confirm the results of other studies on aeglid morphology; however, the information presented by this study regarding variation in the shape of the cheliped propodus is new to the literature. The geometric morphometric approach applied in this study provided useful tools for achieving the proposed objectives.

Keywords: Aeglidae, carapace, cheliped, geometric morphometrics, sexual size dimorphism, sexual shape dimorphism.

\section{Introduction}

Sexual dimorphism is widely known in the animal kingdom (Shine, 1989). Many studies have attempted to use a conventional metric analysis with linear measurements to demonstrate or to provide hypotheses about the adaptive significance of morphological differences between sexes (Gould, 1974; Slatkin, 1984; Hedrick and Temeles, 1989; Katsikaros and Shine, 1997; Abraham, 1998; Green, 2000; Walker and Fell, 2001). Currently, techniques based on geometric morphometric allow the use of landmarks or 
contours to generate multiple variables that can be used to test the variation in body shape shown by different groups, such as species, populations or sexes (Rohlf and Marcus, 1993; Adam et al., 2004; Hepp et al., 2012).

These techniques have been used in different animal groups, including mammals (Klingenberg and Leamy, 2001; CordeiroEstrela et al., 2006; Fornel et al., 2010; Gonzalez et al., 2011), reptiles (Claude et al., 2004), amphibians (Adams and Rohlf, 2000), fishes (Clabaut et al., 2007), insects (Monteiro et al., 2002), mollusks (Rufino et al., 2006a), and crustaceans (Rosenberg, 1997; Rufino et al., 2006b; Silva and Paula, 2008). Because decapod crustaceans have a hard exoskeleton with many spines and sutures, they are considered to represent an interesting group for evaluating the shape of the body with geometric morphometric techniques (Rosenberg, 1997; Clark et al., 2001). In aeglids, this technique was used to study interspecific variation, ontogenetic variation and sexual dimorphism (Giri and Collins, 2004; Collins et al., 2008; Giri and Loy, 2008; Barría et al., 2011; Hepp et al., 2012).

The family Aeglidae Dana, 1852 is currently composed of 72 species (Santos et al., 2012). These species occur in southern South America between São Paulo and Minas Gerais states (in Brazil), to the Duque de York Islands (Chile) (Oyanedel et al., 2011).

Aegla marginata Bond-Buckup and Buckup, 1994 occurs in Brazil from southern São Paulo State to northwestern Santa Catarina State, including the eastern portion of Paraná State (Bond-Buckup and Buckup, 1994). Despite its relatively wide distribution, little information about the species is currently found in the literature. The available information is related to differences in pigmentation (Morachioli, 1994), the occurrence of populations in both epigean and subterranean environments in Parque Estadual Intervales (PEI), Iporanga city, southeastern Brazil (Rocha and Bueno, 2004) and the external abnormalities found in a cave population (Fernandes et al., 2010).

The objective of this study was to analyze the sexual dimorphism in the size and shape of the carapace and the chelipeds through geometric morphometric techniques in a population of $A$. marginata from the Taquaral River in eastern Paraná State, Brazil, to determine whether statistically significant sexual dimorphism occurs. In addition to the carapace, which suitable structures for defining anatomical landmarks, the chelipeds were selected for this study because they represent a secondary sexual character in several groups of crustaceans (Hartnoll, 1978 and 1982; Flores et al., 2002; Castiglioni and Negreiros-Fransozo, 2004; Castiglioni and Coelho, 2011).

\section{Material and Methods}

\section{Samplings}

Aegla marginata were sampled from the Taquaral River, located in the Coastal Basin of Paraná State (Maack, 1968; Bigarella, 1978) within the limits of Marumbi State Park (2526'24”S - 48 55'12”W), in Morretes municipality. The animals were fixed in $4 \%$ formalin and preserved in 75\% ethanol.

Morphometric data were obtained from the carapace of 122 adults ( 47 females and 75 males) and from the major and minor cheliped propodus of 69 adults (29 females and 40 males).

\section{Geometric morphometrics}

Images of the carapaces and cheliped propodus in dorsal view were obtained with a Dino-Lite Pro AM413 digital microscope (AnMo Electronics Corporation, Hsinchu, Taiwan; www.dino-lite.com) with 1.3 mega pixels resolution. Eighteen two-dimensional landmarks were established for the images of the carapace and 10 for the images of the cheliped propodus (Fig. 1).

Landmarks were digitized twice by the same researcher on different days with TPS Dig2 software, version 2.16 (Rohlf, 2010; available in: http://life.bio.sunysb.edu/ morph). A Generalized Procrustes Analysis (GPA) was performed for each body part 

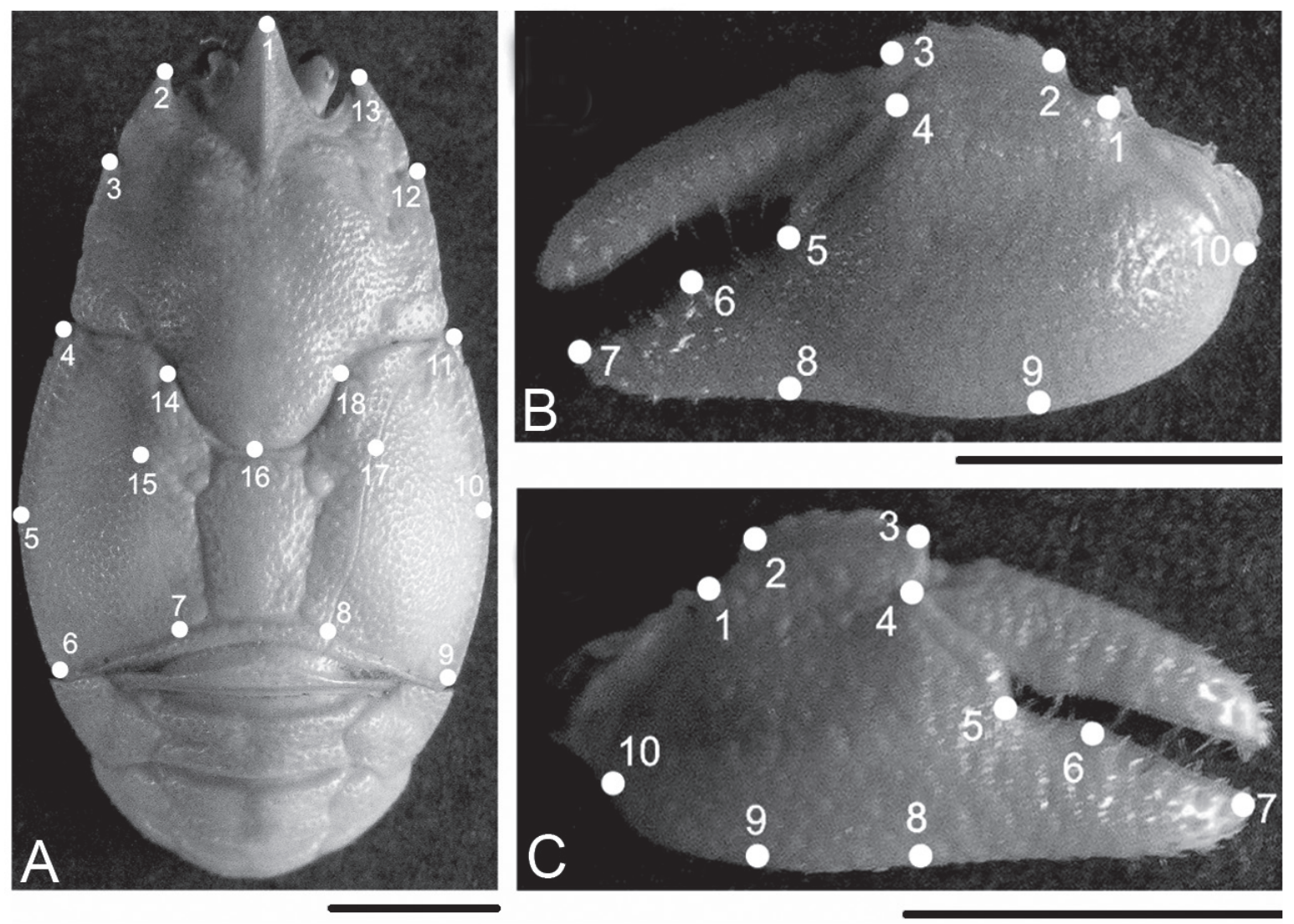

Figure 1. Aegla marginata. (A) Position of the morphological landmarks on the carapace; (B) left cheliped propodus; (C)right cheliped propodus. Scale: $5 \mathrm{~mm}$. (A) 1: Tip of the rostrum; 2 and 13: Tip of antero-lateral spines; 3 and 12: Intersection between the first and second hepatic lobe; 4 and 11: Intersection between the third hepatic lobe and epibranchial tooth; 5 and 10: Intersection between posterior branchial line and posterior "linea aeglica lateralis"; 6 and 9: Posterior vertex of carapace; 7 and 8: Posterior extreme of the longitudinal dorsal line; 14 and 18: Cervical groove; 15 and 17: Anterior extreme of the intersection between branchial line and "linea aeglica dorsalis"; 16: Center-anterior vertex of aureole; (B and C) 1: Inner base of the articulation carpo-propodus; 2: Proximal tip of the cheliped "crista palmar"; 3: Distal tip of the cheliped "crista palmar"; 4: Suture in the intersection between "pré-dactilar" lobe and the base of cheliped "crista palmar"; 5: Base of the fixed finger of the cheliped; 6: Lobular tooth; 7: Tip of the fixed finger of the cheliped; 8: Vertical line through the base of the fixed finger; 9: Vertical line through the proximal base proximal of cheliped "crista palmar"; 10: Outer base of the articulation carpo-propodus.

(carapace, right and left cheliped propodus) to separate the size and shape components of the landmark configuration. GPA is applied by representing landmark configurations by a centroid (the center of mass of a configuration), by calculating the size of the centroid of each configuration for the value one, and by then rotating the landmark configurations to obtain a least squares fit to the corresponding anatomical landmarks (Adams et al., 2004).

The carapace is symmetrical, but its shape can be partitioned into symmetric and asymmetric components (Klingenberg et al., 2002). To analyze sexual dimorphism, only symmetrical components of the carapace shape were used in this study. The size of each body part was estimated as the size of the centroid, defined as the square root of the sum of the squared distances of the constituent points from the centroid of the selected group, in units of millimeters $(\mathrm{mm})$.

\section{Data analysis}

A Student t-test was used to determine whether statistically significant sexual dimorphism was shown by the carapace and cheliped propodus. The analyses were 
Trevisan et al:: Geometric morphometric of Aegla marginata.

performed with $\mathrm{R}$ software ( $\mathrm{R}$ Development Core Team, 2011; available in: www.R-project. org).

To evaluate the occurrence of sexual dimorphism in shape, a principal component analysis (PCA) was performed on the variancecovariance matrix of the residuals from the GPA. The principal component scores were used as new variables to characterize the shape. This approach allowed the scores to be used as independent variables and served to reduce the dimensionality of the data (Klingenberg and Monteiro, 2005; Fornel et al., 2010). Differences in shape between the sexes were tested with a discriminant analysis (DA) in conjunction with a permutation test. This analysis computed the classification percentages and performed a cross-validation between the groups (Viscosi and Cardini, 2011). The analyses were performed with the MorphoJ program (Klingenberg, 2011; available in: http://www.flywings.org.uk)

\section{Results}

Sexual size dimorphism in carapace and cheliped propodus

The carapace size did not differ significantly between male and female $A$. marginata $(\mathrm{t}=-1.84, P=0.068$, mean $\pm \mathrm{SD}$ : females $=26.6 \pm 4.1 \mathrm{~mm}$, males $=27.9 \pm 3.8$ $\mathrm{mm})$. However, the size of the left cheliped propodus $(\mathrm{t}=-2.96, P<0.01)$ and the right cheliped propodus $(\mathrm{t}=-4.62, P<0.01)$ differed significantly between the sexes. The cheliped propodus on both sides was larger in the males than in the females (left cheliped propodus: females $=11.6 \pm 2.1 \mathrm{~mm}$, males $=13.3 \pm 2.4$ $\mathrm{mm}$; right cheliped propodus: females $=10.7$ $\pm 2.0 \mathrm{~mm}$, males $=13.5 \pm 2.9 \mathrm{~mm}$ ).

Sexual dimorphism in the shape of the carapace and cheliped propodus

The shape of the carapace differed significantly between the males and the females (Procrustes distance $=0.020, P<0.001$; Mahalanobis distance $=3.71, P<0.001$ ), with a percentage of correct classification of
90.2\%. The Sexual shape dimorphism of the carapace was related primarily to the variation in landmarks 6 and 7 and in the corresponding homologous landmarks (8 and 9) at the posterior margin of the carapace (Fig. 2). The females showed a wider posterior margin than the males. In contrast, the anterior area in the females was slightly narrower than that in the males due to the small difference in the anterior contour related to the variation in landmarks 2, 3, and 4 and their homologous landmarks $(13,12$, and 11). The tip of the rostrum was slightly longer (landmark 1) and the carapace was slightly shorter (landmark 16) in the females than in the males (Fig. 2).

The shape of the cheliped propodus also differed between the sexes on the left

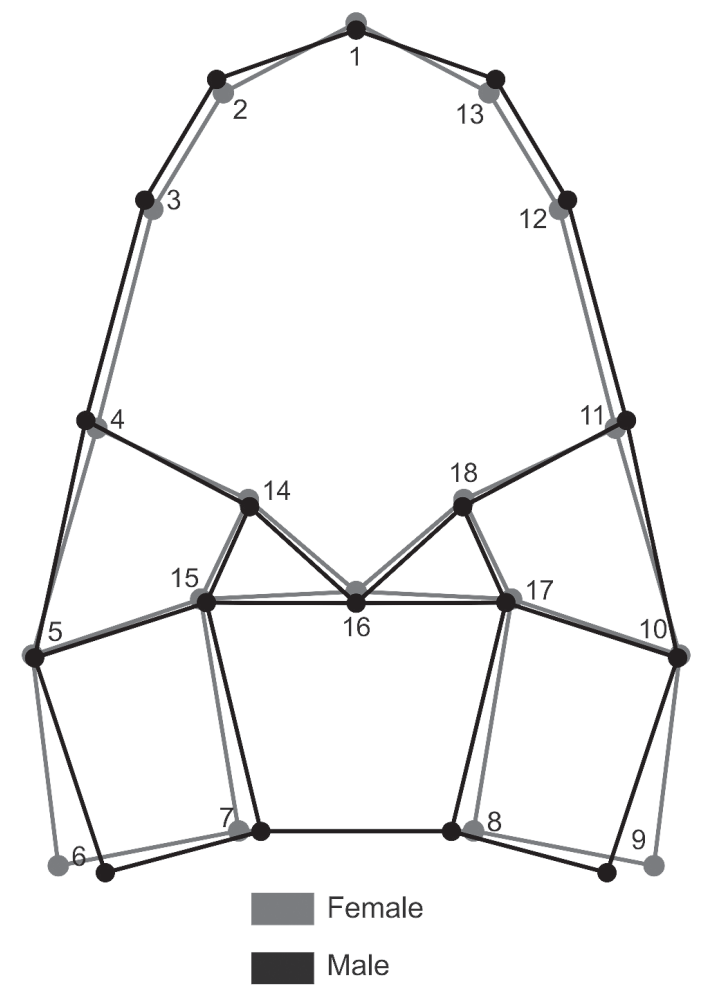

Figure 2. Aegla marginata. Sexual dimorphism in the shape of carapace. Deformations magnified 3 times.

side (Procrustes distance $=0.030, P<0.001$; Mahalanobis distance $=3.26, P<0.001)$ and on the right side (Procrustes distance $=0.039$; $P<0.001$; Mahalanobis distance $=3.92, P<$ $0.001)$. The left cheliped propodus showed a percentage of correct classification of $87.0 \%$. 


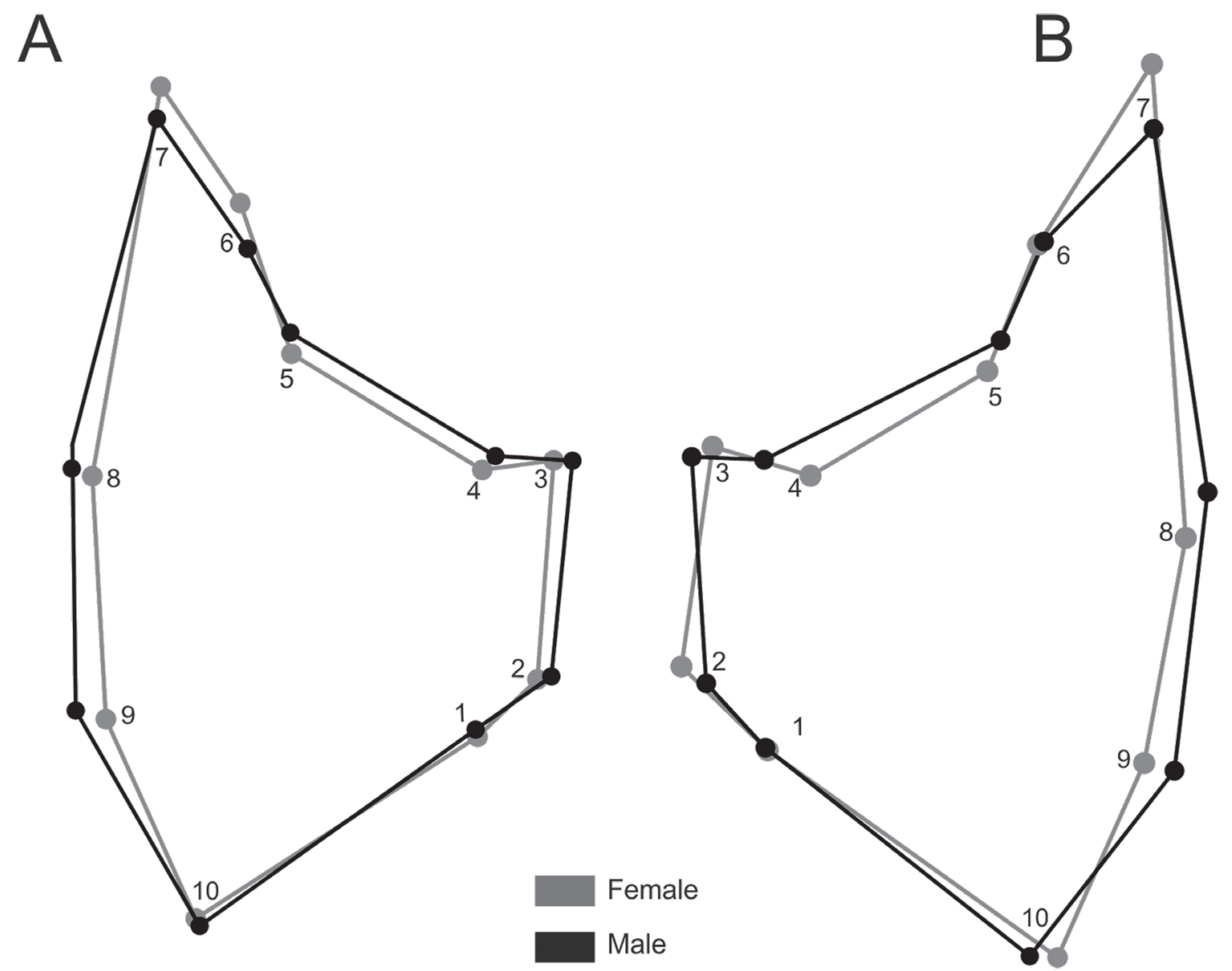

Figure 3. Aegla marginata. Sexual dimorphism in the shape of left (A) and right (B) propodus. Deformations magnified 3 times.

This result showed that the sexes could be accurately distinguished based on the shape of the cheliped. The margin of insertion of the mobile finger (between landmarks 4 and 5) was more concave in the females than in the males. The fixed finger was narrower and longer in the females than in the males (Fig. 3A). The same patterns of variation were observed for the right cheliped propodus (percentage of correct classification, $87.0 \%$ ), except for the margin of articulation with the carpus (between landmarks 1 and 10), which was wider in the females than in the males (Fig. 3B). Overall, the shape of the cheliped propodus was longer and narrower in the females than in the males.

\section{Discussion}

In this study, we found no sexual dimorphism in the size of the carapace of $A$. marginata, although the carapace shape differed between the males and the females. However, both the size and the shape of the right and left cheliped propodus differed between the sexes. We consider that the dimorphism of carapace shape and the size and shape of the cheliped are related to the separate reproductive roles of the sexes.

The size difference between the larger males and the smaller females is the most common feature of aeglid populations from southeastern and southern Brazil: Aegla laevis laevis Latreille, 1818 (Bahamonde and López, 1961), Aegla paulensis Schmitt, 1942 (López, 1965; Cohen et al., 2011), Aegla perobae Hebling and Rodrigues, 1977 (Rodrigues and Hebling, 1978), Aegla castro Schmitti, 1942 from Paraná State (Swiech-Ayoub and Masunari, 2001) and from Sáo Paulo State (Fransozo et al., 2003), Aegla leptodactyla 
Buckup and Rossi, 1977 (Noro and Buckup, 2003), Aegla longirostri Bond-Buckup and Buckup, 1994 (Colpo et al., 2005), Aegla franciscana Buckup and Rossi, 1977 (Gonçalves et al., 2005), Aegla schmitti Hobbs III, 1979 (Teodósio and Masunari, 2009) and Aegla manuinflata Bond-Buckup and Santos, 2009 (Trevisan and Santos, 2011). The sole exception to this pattern is Aegla platensis Schmitti, 1942 from Rio Grande do Sul State (Bueno et al., 2000).

The absence of a statistical difference in carapace size between the sexes in $A$. marginata can be explained in terms of several factors, including differential migration and/or mortality between the sexes and geographical isolation. These factors may act in conjunction with natural and sexual selection to produce the observed size similarity between the sexes (Giesel, 1972; Montague, 1980; Fairbairn and Preziosi, 1994; Fairbairn and Preziosi, 1996). Nutritional status, food availability and genetic factors may also cause this similarity (Tzeng, 2004; Anastasiadou et al., 2009).

It is possible that the variation in carapace shape between the sexes of $A$. marginata occurred as a consequence of relative growth in their body proportions. This growth process is completed in adulthood (Hartnoll, 1974; 1978). The enlarged posterior carapace in females corresponds to the enlargement of the incubatory space and serves to accommodate a large egg mass. This assumption is based on previous studies of relative growth and size at the onset of morphometric maturity in aeglids. These studies include morphological analyses and analyses involving the geometric morphometric of the carapace (Giri and Collins, 2004; Colpo et al., 2005; Viau et al., 2006; Collins et al., 2008; Giri and Loy, 2008; Oliveira and Santos, 2011; Hepp et al., 2012; Trevisan and Santos, 2012). The enlargement of the posterior carapace is a sexually related process that occurs specifically among aeglids. As a result of this process, the abdomen is bent at its midpoint (i.e., the anterior half of the abdomen remains on the dorsal side).

Sexual dimorphism in the width of the abdomen is not found in other groups of
Anomura (e.g., hermit crabs). In studies that discuss issues related to relative growth in Anomura, changes in the rates of allometric growth of the cheliped are the most frequently used markers of the average size at the onset of morphological sexual maturity (Mantelatto and Martinelli, 2001). However, the average length of the abdomen is greater in the females than in the males is some members as the porcelain crab Petrolisthes armatus Gibbes, 1850 , in which positive allometric growth of this structure occurs between the juvenile and adult stages (Miranda and Mantelatto, 2010), as in several species of Aeglidae.

The chelipeds are modified pereiopods. They have attracted considerable attention from carcinologists, not only because of their peculiar morphology but also because of their importance in feeding, sexual behavior, and agonistic activities (Hartnoll, 1982; Mariappan et al., 2000). The chelipeds, like the female abdomen, exhibit allometric growth in several crustacean groups. The allometric growth of the chelipeds is generally positive in males and is highly variable in females, with cases of positive allometry, negative allometry and isometry (for a complete review, see Finney and Abel, 1981; Muino et al., 1990; Garvey and Stein, 1993; Pinheiro and Fransozo, 1993; Grandjean et al., 1997; Mariappan et al., 2000; Trevisan and Santos, 2012).

The finding by this study that both propods are larger in the males of $A$. marginata than in the females suggests the possible functions cited above. It is generally observed in studies of the relative growth of aeglids that the males show greater growth in the cheliped after the transition to adulthood. This difference is one of the factors that produces sexual dimorphism in the group (Colpo et al., 2005; Viau et al., 2006; Oliveira and Santos, 2011; Trevisan and Santos, 2012). This pattern of ontogenetic development is most likely related to variation in the size and shape of the A. marginata chelipeds.

Unfortunately, most previous studies of the growth of the chelipeds in aeglids involved comparisons between the left and right sides of the same individual (e.g., previous studies 
of $A$. paulensis, $A$. perobae and $A$. uruguayana). Assessments of the sexual dimorphism of the chelipeds are scarce for this family. For this reason, interspecific comparisons of this interesting pattern of intraspecific variation are difficult (López, 1965; Rodrigues and Hebling, 1978; Viau et al., 2006). In Aegla franca Schmitt, 1942, both chelipeds show a high degree of sexual dimorphism. In all carapace-length size classes in which both males and females were represented, the males had larger and more robust chelipeds than the females (Bueno and Shimizu, 2009).

The Sexual shape dimorphism of the cheliped propods, in conjunction with the similar carapace size of males and females, indicates the need by the males for a wider palm and palmar region between the crest and the base of the fixed finger. The result of this characteristic is that the fixed finger is shorter and stronger in the males than in the females. The extension of the cheliped propod may be related to the insertion of different muscles in the region of the cheliped palm. A shorter and rugged fixed finger can provides to males with the strength needed to perform agonistic behaviors related to females or territories or to guard the females after copulation, as observed in the males of $A$. platensis (Almerão et al., 2010). Moreover, the thinner and more delicate fixed finger of the females can be used to assist in the process of self-cleaning of the abdominal camera and sensory structures after egg laying (Almerão et al., 2010).

Although few studies using the technique of geometric morphometric are available for aeglid species (Giri and Collins, 2004; Collins et al., 2008; Giri and Loy, 2008; Barría et al., 2011; Hepp et al., 2012), this technique has provided robust results and has allowed a precise interpretation of sexual dimorphism in shape and size in $A$. marginata.

\section{Acknowledgments}

We are grateful to the editor and three anonymous reviewers for their insightful comments, which greatly improved the manuscript. The authors thank the Postgraduate Programs in Zoology and in Entomology, Federal University of Paraná for providing all the laboratory facilities for this study. This research was supported by grants from the Coordenação de Aperfeiçoamento de Pessoal de Nível Superior (CAPES) and Conselho Nacional de Desenvolvimento Científico e Tecnológico (CNPq).

\section{References}

Abraham, J.N. 1998. La saboteuse: An ecological theory of sexual dimorphism in animals. Acta Biotheoretica, 46: 23-35.

Adams, D.C. and Rohlf, F.J. 2000. Ecological character displacement in plethodon: biomechanical differences found from a geometric morphometric study. Proceedings of the National Academy of Sciences of the United States of America, 97(8): 4106-4111.

Adams, D.C.; Rohlf, F.J and Slice, D.E. 2004. Geometric morphometrics: ten years of progress following the 'revolution'. Italian Journal of Zoology, 71: 5-16.

Almerão, M.; Bond-Buckup, G. and Mendonça Jr. M de S. 2010. Mating behavior of Aegla platensis (Crustacea, Anomura, Aeglidae) under laboratory conditions. Journal of Ethology, 28(1): 87-94.

Anastasiadou, C.; Liasko, R. and Leonardos, I.D. 2009. Biometric analysis of lacustrine and riverine populations of Palaemonetes antennarius ( $\mathrm{H}$. Milne Edwards, 1837) (Crustacea, Decapoda, Palaemonidae) from north-western Greece. Limnologica, 39: 244-254.

Bahamonde, N. and López, M.T. 1961. Estudios biológicos en la populación de Aegla laevis laevis (Latreille) de el Monte (Crustacea, Decapoda, Anomura). Investigaciones Zoológicas Chilenas, 7: 1958.

Barría, E.M.; Sepúlveda, R.D. and Jara, C.G. 2011. Morphologic variation in Aegla 
Leach (Decapoda: Reptantia: Aeglidae) from central-southern Chile: interspecific differences, sexual dimorphism, and spatial segregation. Journal of Crustacean Biology, 31(2): 231-239.

Biagi, R. and Mantelatto, F.L. 2006. Relative growth and sexual maturity of the hermit crab Paguristes erythrops (Anomura, Diogenidae) from South Atlantic. Hydrobiologia, 559(1): 247-254.

Bigarella, J.J. 1978. A Serra do Mar e a porção ocidental do Estado do Paraná. Curitiba. Governo do Paraná, Secretaria de Estado do Planejamento e Associação de defesa e Educação Ambiental. 248p.

Bond-Buckup, G. and Buckup, L. 1994. A família Aeglidae (Crustacea, Decapoda, Anomura). Arquivos de Zoologia, 32: 159346.

Buckup, L. and Rossi, A. 1979. O gênero Aegla no Brasil (Crustacea, Decapoda, Anomura, Aeglidae. Revista Brasileira de Biologia, 37(4): 879-892.

Bueno, A.A.P.; Bond-Buckup, G. and Buckup, L. 2000. Crescimento de Aegla platensis em ambiente natural (Crustacea, Decapoda, Aeglidae). Revista Brasileira de Zoologia, 17(1): 43-49.

Bueno, S.L.S. and Shimizu, R.M. 2009. Allometric growth, sexual maturity, and adult male chelae dimorphism in Aegla franca (Decapoda: Anomura: Aeglidae). Journal of Crustacean Biology, 29(3): 317328.

Castiglioni, D.S. and Negreiros-Fransozo, M.L. 2004. Comparative analysis of the relative growth of Uca rapax (Smith) (Crustacea, Ocypodidae) from two mangroves in São Paulo, Brazil. Revista Brasileira de Zoologia, 21(1): 137-144.

Castiglioni, D.S. and Coelho, P.A. 2011. Determinação da maturidade sexual de Ucides cordatus (Crustacea, Brachyura, Ucididae) em duas áreas de manguezal do litoral sul de Pernambuco, Brasil. Iheringia, Série Zoologia, 101(1-2): 138-144.

Clabaut, C.; Bunje, P.; Salzburger, W. and Meyer, A. 2007. Geometric morphometric analyses provide evidence for the adaptive character of the Tanganyikan cichlid radiations. Evolution, 61: 560-578.

Clark P.F.; Neale M. and Rainbow P.S. 2001. A morphometric analysis of regional variation in Carcinus Leach, 1814 (Brachyura: Portunidae: Carcininae) with particular reference to the status of the two species $C$. maenas (Linnaeus, 1758) and $C$. aestuarii Nardo, 1847. Journal of Crustacean Biology, 21: 288-303.

Claude, J.; Pritchard, P.C.H.; Tong, H.; Paradis, E. and Auffray, J. 2004. Ecological correlates and evolutionary divergence in the skull of turtles: a geometric morphometric assessment. Systematic Biology, 53(6): 933948.

Cohen, F.P.A.; Takano, B.F.; Shimizu, R.M. and Bueno, S.L.S. 2011. Life cycle and population structure of Aegla paulensis (Decapoda: Anomura: Aeglidae). Journal of Crustacean Biology, 31(3): 389-395.

Collins, P.A.; Giri, F. and Williner, V. 2008. Sexual maturity and ontogenetic shape variations in the freshwater anomuran crab, Aegla uruguayana (Decapoda, Aeglidae). Invertebrate Reproduction and Development, 52(1-2): 113-119.

Colpo, K.D.; Ribeiro, L.D. and Santos, S. 2005. Population biology of the freshwater Anomura Aegla longirostri (Aeglidae) from south Brazilian streams. Journal of Crustacean Biology, 25(3): 495-499.

Cordeiro-Estrela, P.; Baylac, M.; Denys, C. and Marinho-Filho, J. 2006. Interspecific patterns of skull variation between sympatric Brazilian vesper mice: geometric morphometrics assessment. Journal of Mammalogy, 87(6): 1270-1279.

Dana, J.D. 1852. Crustacea. Part 1. In: United States Exploring Expedition during the Years 1838, 1839, 1840, 1841, 1842, Under the Command of Charles Wilkes, U.S.N., S.1. Vol. 13: 475-478.

Fairbairn, D.J. and Preziosi, R.F. 1994. Sexual selection and evolution of allometry for sexual size dimorphism in the water strider, Aquarius remigis. The American Naturalist, 144(1): 101-118. 
Fairbairn, D.J. and Preziosi, R.F. 1996. Sexual selection and evolution of sexual size dimorphism in the water strider, Aquarius remigis. The American Naturalist, 144(1): 101-118.

Fernandes, C.S.; Gregati, R.A. and Bichuette, M.E. 2010. The first record of external abnormalities in the subterranean Aegla marginata Bond-Buckup and Buckup, 1994 (Crustacea: Decapoda: Aeglidae), from a karst area of Southeastern Brazil. Subterranean Biology, 8: 33-38.

Finney, W.C. and Abele, L.G. 1981. Allometric variation and sexual maturity in the obligate coral commensal Trapezia ferruginea Latreille (Decapoda, Xanthidae). Crustaceana, 41: 113-130.

Flores, A.A.V.; Saraiva, J. and Paula, J. 2002. Sexual maturity, reproductive cycles and juvenile recruitment of Perisesarma guttatum (Brachyura, Sesarmidae) at Ponta Rasa mangrove swamp, Inhaca Island, Mozambique. Journal of Crustacean Biology, 22(1): 143-156.

Fornel, R.; Cordeiro-Estrela, P. and De Freitas, T.R.O. 2010. Skull shape and size variation in Ctenomys minutus (Rodentia: Ctenomyidae) in geographical, chromosomal polymorphism, and environmental contexts. Biological Journal of Linnean Society, 101: 705-720.

Fransozo, A.; Costa, R.C.; Reigada, A.L.D. and Nakagaki, J.M. 2003. Population structure of Aegla castro Schmitt, 1942 (Crustacea: Anomura: Aeglidae) from Itatinga (SP), Brazil. Acta Limnologica Brasiliensis, 15(2): 13-20.

Garvey, J.E. and Stein, R.A. 1993. Evaluating how chela size influences the invasion potential of an introduced crayfish (Orconectes rusticus). American Midland Naturalist, 129: 172-181.

Gibbes, L.R. 1850. On the carcinological collections of the cabinets of natural history in the United States; with an enumeration of the species contained therein, and descriptions of new species. Proceedings of the American Association for the Advancement of Science, 3: 165-201.
Giesel, J.T. 1972. Sex ratio, rate of evolution, and environmental heterogeneity. American Naturalist, 106: 380-387.

Giri, F. and Collins, P. 2004. A geometric morphometric analysis of two sympatric species of the family Aeglidae (Crustacea, Decapoda, Anomura) from the La Plata basin. Italian Journal of Zoology, 71: 85-88.

Giri, F. and Loy, A. 2008. Size and shape variation of two freshwater crabs in Argentinean Patagonia: the influence of sexual dimorphism, habitat, and species interactions. Journal of Crustacean Biology, 28(1): 37-45.

Gonçalves, R.S.; Castiglioni, D.S. and BondBuckup, G. 2006. Ecologia populacional de Aegla franciscana (Crustacea, Decapoda, Anomura) em São Francisco de Paula, RS, Brasil. Iheringia, Série Zoologia, 96(1): 109114.

Grandjean, F.; Romain, D.; Avila-Zarza, C.; Bramard, M.; Souty-Grosset, C. and Mocquard, J.P. 1997. Morphometry, sexual dimorphism and size at maturity of the white-clawed crayfish, Austropotamobius pallipes pallipes (Lereboullet) from a wild French population at Deux-Sevres (Decapoda, Astacidea). Crustaceana, 70: 31-44.

Green, A.J. 2000. The scaling and selection of sexually dimorphic characters: an example using the Marbled Teal. Journal of Avian Biology, 31: 345-350.

Gonzalez, P.N.; Perez, I.S. and Bernal, V. 2011. Ontogenetic allometry and cranial shape diversification among human populations from South America. The Anatomical Record, 294: 1864-1874.

Gould S.J. 1974. The origin and function of 'bizarre' structures: antler size and skull size in the 'irish elk' Megaloceros giganteus. Evolution, 28: 191-220.

Hartnoll, R.G. 1974. Variation in growth patterns between some secondary sexual characters in crabs. Crustaceana, 27: 131136.

Hartnoll, R.G. 1978. The determination of relative growth in Crustacea. Crustaceana, 34: 281-293. 
Hartnoll, R.G. 1982. Growth, In: Bliss, D.E. (ed), The biology of Crustacea, Embriology, Morphology and Genetics. New York, Academic Press, Inc., Vol. 2: 111-196.

Hebling, N.J. and Rodrigues, W. 1977. Sobre uma nova espécie brasileira do gênero Aegla Leach, 1820 (Decapoda, Anomura). Papéis Avulsos de Zoologia, 30(19): 289-294.

Hedrick, A.V. and Temeles, E.J. 1989. The evolution of sexual dimorphism in animals: hypotheses and tests. Trends in Ecology and Evolution, 4: 136-138.

Hepp, L.U.; Fornel, R.; Restello, R.M.; Trevisan, A. and Santos, S. 2012. Intraspecific morphological variation in a freshwater crustacean Aegla plana (Anomura) in southern Brazil: effects of geographical segregation on carapace shape. Journal of Crustacean Biology, 32(4): 511518.

Hobbs III, H.H. 1978 A new species of the South American genus Aegla from Paraná, Brazil (Crustacea: Anomura: Aeglidae). Proceedings of the Biological Society of Washington, 91(4): 982-988.

Katsikaros K. and Shine R. 1997. Sexual dimorphism in the tusked frog, Adelotus brevis (Anura: Myobatrachidae): the roles of natural and sexual selection. Biological Journal of the Linnean Society, 60: 39-51.

Klingenberg, C.P. and Leamy, L.J. 2001. Quantitative genetics of geometric shape in the mouse mandible. Evolution, 55(11): 2342-2352.

Klingenberg, C.P.; Barluenga, M. and Meyer, A. 2002. Shape analysis of symmetric structures: quantifying variation among individuals and asymmetry. Evolution, 56: 1909-1920.

Klingenberg, C.P. and Monteiro, L.R. 2005. Distances and directions in multidimensional shape spaces: implications for morphometric applications. Systematic Biology, 54: 678-688.

Klingenberg, C.P. 2011. MorphoJ: an integrated software package for geometric morphometrics. Molecular Ecology Resources, 11: 353-357.

Latreille, M. 1818. Crustacés, Arachnides et Insects. In: G. Cuvier (ed), Le règne animal distribué d'aprés son organisation: pour servir de base à l'histoire naturelle des animaux et d'introduction à l'anatomie comparée/par M. le cher, Cuvier. Avec figures, dessinées d'après nature. Paris. Vol. 3.

López, M.T. 1965. Estudios biologicos en Aegla odebrechtii paulensis, Schmitt (Crustacea, Decapoda, Anomura). Boletim de Zoologia, Faculdade de Filosofia, Ciências e Letras, 25: 301-315.

Maack, R. 1968. Geografia física do Estado do Paraná. Curitiba. BADEP. 350p.

Mantelatto, F.L. and Martinelli, J.M. 2001. Relative growth and sexual dimorphism of the South Atlantic hermit crab Loxopagurus loxochelis (Anomura, Diogenidae) from Ubatuba, Brazil. Journal of Natural History, 35(3): 429-437.

Mariappan, P.; Balasundaram, C. and Schmitz, B. 2000. Decapod crustacean cheliped: an overview. Journal of Biosciences, 25: 301313.

Miranda, I. and Mantelatto, F.L. 2010. Sexual maturity and relative growth of the porcellanid crab Petrolisthes armatus (Gibbebs, 1850) from a remnant mangrove area. Nauplius, 18(1): 87-93.

Montague, C.L. 1980. A natural history of temperate Western Atlantic fiddler crabs (Genus $U c a$ ) with reference to their impact on the salt marsh. Contributions of Marine Science, 23: 25-55.

Monteiro, L.R.; Diniz-Filho, J.A.; Reis, S.F. and Araújo, E.D. 2002. Geometric estimates of heritability in biological shape. Evolution, 56(3): 563-572.

Morachiolli, N. 1994. Estudo da biologia de Aegla spp. Cavernícolas do Vale do Alto Ribeira, São Paulo (Crustacea: Anomura: Aeglidae). Master Thesis - Instituto de Biociências, Universidade de São Paulo, São Paulo, Brazil, 148pp.

Muino, R.; Fernandez, L.; GonzalezGurraiaran, E.; Freire, J. and Vilar, J.A. 1999. Size at maturity of Liocarcinus depurator (Brachyura: Portunidae): a reproductive and morphometric study. Journal of the 
Marine Biological Association of the United Kingdom, 79: 29-303.

Noro, C.K. and Buckup, L. 2003. O crescimento de Aegla leptodactyla Buckup and Rossi (Crustacea, Anomura, Aeglidae). Revista Brasileira de Zoologia, 20(2): 191198.

Oliveira, D. and Santos, S. 2011. Maturidade sexual morfológica de Aegla platensis (Crustacea, Decapoda, Anomura) no Lajeado Bonito, norte do estado do Rio Grande do Sul, Brasil. Iheringia, Série Zoologia, 101(1-2): 127-130.

Oyanedel, A.; Voldovinos, C.; Sandoval, N.; Moya, C.; Kiessling, G.; Salvo, J. and Olmos, V. 2011. The southernmost freshwater anomurans of the word: geographic distribution and new records of Patagonian eglids (Decapoda: Aeglidae). Journal of Crustacean Biology, 31(3): 396400.

Pinheiro, M.A.A. and Fransozo, A. 1993. Relative growth of the speckled swimming crab Arenaeus cribrarius (Lamarck, 1818) (Brachyura, Portunidae), near Ubatuba, State of São Paulo, Brazil. Crustaceana, 65: 377-389.

R Development Core Team (2011). R: A language and environment for statistical computing. R Foundation for Statistical Computing, Vienna, Austria. ISBN 3-900051-07-0, URL http:/www.Rproject.org/.

Rocha, S.S. and Bueno, S.L.S. 2004. Crustáceos decápodes de água doce com ocorrência no Vale do Ribeira de Iguape e Rios Costeiros adjacentes, São Paulo, Brasil. Revista Brasileira de Zoologia, 21(4): 10011010.

Rodrigues, W. and Hebling, N.J. 1978. Estudos biológicos em Aegla perobae Hebling e Rodrigues, 1977 (Decapoda, Anomura). Revista Brasileira de Biologia, 38(2): 383-390.

Rohlf, F.J. and Marcus, L.F. 1993. A revolution in morphometrics. Trends in Ecology and Evolution, 8: 129-132.

Rohlf, F.J. 2010. tpsDig, digitize landmarks and outlines, version 2.16. Department of
Ecology and Evolution, State University of New York at Stony Brook.

Rosenberg, M.S. 1997. Evolution of shape differences between the major and minor cheliped of Uca pugnax (Decapoda: Ocypodidae). Journal of Crustacean Biology, 17(1): 52-59.

Rufino, M.M.; Gaspar, M.B.; Pereira, A.M. and Vasconcelos, P. 2006a. Use of shape to distinguish Chamelea gallina and Chamelea striatula (Bivalvia: Veneridae): linear and geometric morphometric methods. Journal of Morphology, 267: 1433-1440.

Rufino, M.M.; Abello, P. and Yule, A.B. 2006b. Geographic and gender shape differences in the carapace of Liocarcinus depurator (Brachyura: Portunidae) using geometric morphometrics and the influence of a digitizing method. Journal of Zoology, 269: 458-465.

Santos, S.; Bond-Buckup, G.; Perez-Losada, M.; Santos-Bartholomei, M.L. and Buckup, L. 2009. Aegla manuinflata, a new species of freshwater anomuran (Decapoda: Anomura: Aeglidae) from Brazil, determined by morphological and genetic characters. Zootaxa, 2088: 31-40.

Santos, S.; Bond-Buckup, G.; Buckup, L.; Pérez-Losada, M.; Finley, M. and Crandall, K.A. 2012. Three new species of Aegla (Anomura) freshwater crabs from the upper Uruguay River hydrographic basin in Brazil. Journal of Crustacean Biology, 32 (4): 529-540.

Schmitt, W.L. 1942. The species of Aegla, endemic South American fresh-water crustaceans. Proceedings of the United States National Museum, 91: 431-524.

Shine, R. 1989. Ecological Causes for the evolution of sexual dimorphism: a review of the evidence. The Quarterly Review of Biology, 64(4): 419-461.

Silva, I.C. and Paula, J. 2008. Is there a better chela to use for geometric morphometric differentiation in brachyuran crabs? A case study using Pachygrapsus marmoratus and Carcinus maenas. Journal of the Marine Biological Association of the United Kingdom, 88(5): 941-953. 
Slatkin, M. 1984. Ecological causes of sexual dimorphism. Evolution, 38: 622-630.

Swiech-Ayoub, B.P. and Masunari, S. 2001. Flutuaçóes temporal e espacial de abundância e composição de tamanho de Aegla castro Schmitt (Crustacea, Anomura, Aeglidae) no Buraco do Padre, Ponta Grossa, Paraná, Brasil. Revista Brasileira de Zoologia, 18(3): 1003-1017.

Teodósio, E.A.O. and Masunari, S. 2009. Estrutura populacional de Aegla schmitti (Crustacea: Anomura: Aeglidae) nos reservatórios dos Mananciais da Serra, Piraquara, Paraná, Brasil. Zoologia, 26(1): 19-24.

Trevisan, A. and Santos, S. 2011. Crescimento de Aegla manuinflata (Decapoda, Anomura, Aeglidae) em ambiente natural. Iheringia, Série Zoologia, 101(4): 336-342.

Trevisan, A. and Santos, S. 2012. Morphological sexual maturity, sexual dimorphism and heterochely in Aegla manuinflata (Anomura). Journal of Crustacean Biology, 32 (4): 519-527.

Viau, V.E.; López Greco, L.S.; Bond-Buckup, G. and Rodríguez, E.M. 2006. Size at onset of sexual maturity in anomuran crab, Aegla uruguayana (Aeglidae). Acta Zoologica, 87: 253-264.

Viscosi, V. and Cardini, A. 2011. Leaf morphology, taxonomy and geometric morphometrics: a simplified protocol for beginners. PLoSONE, 6(10): e25630. doi:10.1371/journal.pone.0025630.

Tzeng, T.D. 2004. Stock identification of sword prawn Parapenaeopsis hardwichii in the East China Sea and Taiwan Strait inferred by morphological variation. Fisheries Science, 70: 758-764.

Walker, K.A. and Fell, R.D. 2001. Courtship roles of male and female European earwigs, Forficula auricularia L. (Dermaptera: Forficulidae), and sexual use of forceps. Journal of Insect Behavior, 14: 1-17. 